\title{
Prediksi Awal Ramadhan Menggunakan Metode Fuzzy Tsukamoto
}

\author{
${ }^{1}$ Zuraida Zurzaq, ${ }^{2}$ Silviani, ${ }^{3}$ Mohammad Mukhlis \\ ${ }^{1}$ IAIN Jember, Jl. Mataram No. 1 Mangli, (0331) 487550 \\ ${ }^{2}$ IAIN Jember, Jl. Mataram No. 1 Mangli, (0331) 487550 \\ ${ }^{3}$ IAIN Jember, Jl. Mataram No. 1 Mangli, (0331) 487550 \\ e-mail: zuraidazurzaq@gmail.com
}

\begin{abstract}
Abstrak
Penentuan awal Ramadhan pada umumnya menggunakan metode rukyatul hilal dan hisab. Permasalahan yang sering terjadi ketika menggunakan kedua metode tersebut yakni tidak menentunya pola dalam menentukan awal Ramadhan sehingga terjadi perbedaan pendapat. Salah satu metode yang dapat digunakan untuk memprediksi awal Ramadhan yakni metode Tsukamoto sebab metode ini dapat menangani data-data yang tidak linier. Penelitian ini menggunakan variabel input berupa rasio awal Ramadhan satu ke awal Ramadhan berikutnya dari enam periode Ramadhan yang lalu yakni dari tahun 2014-2020 dan lama puasa Ramadhan pada setiap periodenya, sedangkan variabel output berupa awal Ramadhan. Hasil perhitungan menggunakan metode Tsukamoto tidak berbeda jauh dengan hasil perhitungan secara manual yakni untuk awal Ramadhan tahun 2020 jatuh 356 hari setelah awal Ramadhan pada tahun 2019, tanpa mengurangi ketepatan dalam perhitungan, metode ini dapat digunakan untuk mempermudah dalam menentukan prediksi awal Ramadhan.
\end{abstract}

Kata Kunci: Awal Ramadhan, logika fuzzy, Tsukamoto

\section{PENDAHULUAN}

Perbedaan pendapat dalam penentuan awal Ramadhan sering terjadi, sebab menentukan awal Ramadhan bukan hal yang mudah khususnya di Indonesia yang merupakan Negara kepulauan dengan tiga zona waktu. Metode yang biasa digunakan dalam menentukan awal Ramadhan di Indonesia ada dua yakni rukyatul hilal dan hisab. Hisab adalah metode penentuan awal bulan hijriyah dengan pendekatan matematika dan astronomi. Mazhab hisab menggunakan dalil dari surat Yunus ayat 5. Sedangkan, Rukyatul hilal adalah proses penentuan awal bulan hijriyah dengan melihat hilal secara langsung(BJ Habibie, 1994). Mazhab rukyah menyandarkan dalilnya pada sabda Nabi saw., yaitu:

"Apabila melihat tanggal (hilal) maka berpuasalah dan apabila kamu melihat tanggal (hilal) maka berbukalah. Jika penglihatanmu terhadap bulan tertutup oleh awan, maka kadarkanlah bulan itu."

Merukyah dengan mata telanjang ternyata tidak lebih mudah daripada menghisab. Bukan karena tertutup awan tetapi juga faktor lain seperti polusi sehingga dapat menyesatkan mata. Oleh karena itu, perlu alternatif lain untuk mempermudah dalam penentuan prediksi 
awal Ramadhan. Salah satunya menggunakan metode kecerdasan buatan yang bisa diterapkan untuk prediksi seperti logika fuzzy.

Logika fuzzy atau logika yang digunakan untuk menggambarkan ketidakjelasan merupakan sebuah metodologi "berhitung" dengan variabel kata-kata (linguistic variable), sebagai pengganti berhitung dengan bilangan. Kata-kata yang digunakan dalam logika fuzzy tidak sepresisi dengan bilangan, namun kata-kata lebih dekat dengan instuisi manusia. Lotfi Zadeh (1960) mengemukakan bahwa fuzzy merupakan suatu aspek ketidaktentuan yang berbeda dengan keacakan. Dalam fuzzy dikenal derajat kenggotaan yang memiliki interval $[0,1]$. Dalam teori logika fuzzy suatu nilai bisa bernilai benar atau salah secara bersama, namun berapa besar keberadaan dan kesalahan tergantung pada bobot keanggotaan yang dimilikinya(Kusumadewi dan Hartati, 2006). Penggunaan logika fuzzy didasarkan pada keunggulan logika fuzzy yakni mampu memodelkan fungsi-fungsi yang tidak linier, didasarkan pada bahasa alami yang mudah dimengerti, dan dapat toleransi terhadap data yang tidak tepat. Selain itu, logika fuzzy juga dapat diaplikasikan dengan baik untuk menentukan suatu kesimpulan atau hasil dari data input dan output yang akan diproses. Permasalahannya adalah menentukan prediksi awal Ramadhan pada tahun yang akan datang. Dalam penelitian ini akan membahas mengenai prediksi awal Ramadhan pada tahun 2020. Prediksi ini akan dilakukan dengan menggunakan logika fuzzy karena logika fuzzy memiliki kemampuan dalam proses penalaran secara bahasa sehingga dalam perancangannya tidak memerlukan persamaan matematik yang rumit.

Dalam logika fuzzy terdapat 3 jenis fuzzy, yaitu: Tsukamoto, Mamdani, dan Sugeno. Pada kasus memprediksi awal Ramadhan tahun berikutnya logika fuzzy yang akan dipakai adalah Tsukamoto. Hal ini dikarenakan fuzzy Tsukamoto memiliki penalaran fuzzy yang cukup mudah dipahami dan penggunaannya lebih pada Humanis Controll. Sedangkan, fuzzy Mamdani lebih pada Humanis dan fuzzy Sugeno lebih pada Control. Kelebihan lain dari metode Tsukamoto adalah memiliki toleransi terhadap data-data yang tidak tepat. Pada metode ini setiap aturan dipresentasikan menggunakan himpunan-himpunan fuzzy, dengan keanggotaan yang monoton. Untuk menentukan nilai output yang tegas dilakukan dengan mengubah input menjadi suatu bilangan pada domain himpunan fuzzy tersebut. Cara ini disebut dengan metode defuzzifikasi. Metode Tsukamoto menggunakan metode defuzzifikasi rata-rata terpusat dan implikasi setiap aturan harus berbentuk implikasi "sebab-akibat" dimana antara antesedon dan konsekuen harus ada hubungannya. Keunggulan metode ini ditunjukkan dari beberapa referensi seperti pada jurnal "Metode logika fuzzy Tsukamoto Dalam Pengambilan Keputusan Penerimaan Beasiswa”. Pada jurnal tersebut menghasilkan 
keputusan pemberian beasiswa secara objektif. Dan pada jurnal Internasional "Temperature Control using Fuzzy Logic". Pada kasus tersebut menyimpulkan bahwa teknologi dengan menggunakan fuzzy ini tidak sulit untuk memprediksi dan hasilnya sesuai dengan harapan.

\section{METODE PENELITIAN}

Penelitian ini menggunakan metode Tsukamoto dengan data historis rasio awal Ramadhan ke awal Ramadhan berikutnya dari enam periode Ramadhan yang lalu yakni 2014-2020 dan lama puasa Ramadhan pada setiap periodenya. Adapun tahapan pada metode Tsukamoto sebagai berikut:

1. Membentuk himpunan fuzzy.

Himpunan fuzzy merupakan suatu grup yang mewakili kondisi atau keadaan tertentu dalam suatu variabel fuzzy(Mazenda, Soebroto, \& Dewi, 2015). Sedangkan, variabel linguistik yang digunakan berupa variabel input dan variabel output yang dibagi menjadi satu atau lebih himpunan fuzzy.

\section{Fuzifikasi}

Proses fuzifikasi didefinisikan sebagai perhitungan nilai input menjadi derajat keanggotaan. Perhitungan dalam proses ini didasarkan pada batas-batas fungsi keanggotaan(Restuputri, Mahmudy, \& Cholissodin, 2015).

3. Pembentukan basis pengetahuan fuzzy (Rule dalam bentuk IF... THEN)

4. Implikasi dengan fungsi MIN untuk mendapatkan nilai $\alpha$-predikat tiap-tiap rule $(\alpha 1, \alpha 2, \alpha 3, \ldots \ldots \ldots \alpha n)$ Kemudian masing-masing nilai $\alpha$-predikat ini digunakan untuk menghitung keluaran hasil inferensi secara tegas (crisp) masing-masing rule $(z 1, z 2, z 3, \ldots \ldots \ldots z n)$

5. Defuzzyfikasi

Defuzzyfikasi merupakan proses mengubah himpunan fuzzy keluaran menjadi keluaran tegas (crisp). Defuzzyfikasi menggunkan metode rat-rata yang dirumuskan sebagai berikut:

$$
Z=\frac{\sum\left(a_{i} x z_{i}\right)}{\sum a_{i}}
$$

Keterangan: $\quad Z=$ Variabel input

$a_{i}=$ Nilai $\alpha$-predikat

$z i=$ Nilai variabel output 


\section{HASIL DAN PEMBAHASAN}

Pada penelitian ini akan ditampilkan hasil prediksi awal Ramadhan tahun 2020. Data yang digunakan adalah data historis rasio awal Ramadhan satu ke awal Ramadhan berikutnya dari enam periode Ramadhan yang lalu dan lama puasa Ramadhan pada setiap periodenya. Berikut ini adalah data mengenai rasio awal Ramadhan ke awal Ramadhan berikutnya dan lama puasa Ramadhan pada setiap periodenya dari tahun 2014-2020.

Tabel 1. Data rasio awal Ramadhan ke Ramadhan berikutnya dan lama masa berpuasa pada setiap periodenya

\begin{tabular}{ccc}
\hline Periode & $\begin{array}{c}\text { Rasio Awal Ramadhan ke } \\
\text { Awal Ramadhan } \\
\text { berikutnya }\end{array}$ & $\begin{array}{c}\text { Lama Puasa } \\
\text { Ramadhan Pada } \\
\text { Setiap Periode }\end{array}$ \\
\hline $2014-2015$ & 355 & 30 \\
$2015-2016$ & 353 & 29 \\
$2016-2017$ & 356 & 30 \\
$2017-2018$ & 356 & 29 \\
$2018-2019$ & 355 & 30 \\
$2019-2020$ & 355 & 30 \\
\hline
\end{tabular}

Berikut ini adalah langkah-langkah metode Tsukamoto:

1. Penentuan himpunan fuzzy sebagai berikut:

Tabel 2. Himpunan Fuzzy

\begin{tabular}{ccccc}
\hline \multirow{2}{*}{ Fungsi } & Variabel & $\begin{array}{c}\text { Nama Himpunan } \\
\text { Fuzzy }\end{array}$ & $\begin{array}{c}\text { Semesta } \\
\text { Pembicaraan }\end{array}$ & Domain \\
\hline \multirow{3}{*}{ Input } & $\begin{array}{c}\text { Rasio Awal Ramadhan } \\
\text { ke Awal Ramadhan } \\
\text { berikutnya }\end{array}$ & Banyak & {$[353-356]$} & {$[353-356]$} \\
& $\begin{array}{c}\text { Lama Puasa Ramadhan } \\
\text { Pada Setiap Periode }\end{array}$ & Pedikit & {$[353-356]$} & {$[353-356]$} \\
& Panjang & {$[29-30]$} & {$[29-30]$} \\
Output & Pendek & {$[29-30]$} & {$[29-30]$} \\
& $\begin{array}{c}\text { Ramadhan } \\
\end{array}$ & Jauh & {$[350-365]$} & {$[350-365]$} \\
& Dekat & {$[350-365]$} & {$[350-365]$} \\
\hline
\end{tabular}

Fungsi keanggotaan untuk setiap variabel berbentuk kurva bahu yang digambarkan pada tabel berikut ini:

Tabel 3. Representasi Kurva dan Fungsi Keanggotaan Setiap Variabel

\begin{tabular}{|l|l|}
\hline Representasi Kurva & Fungsi Keanggotaan \\
\hline
\end{tabular}




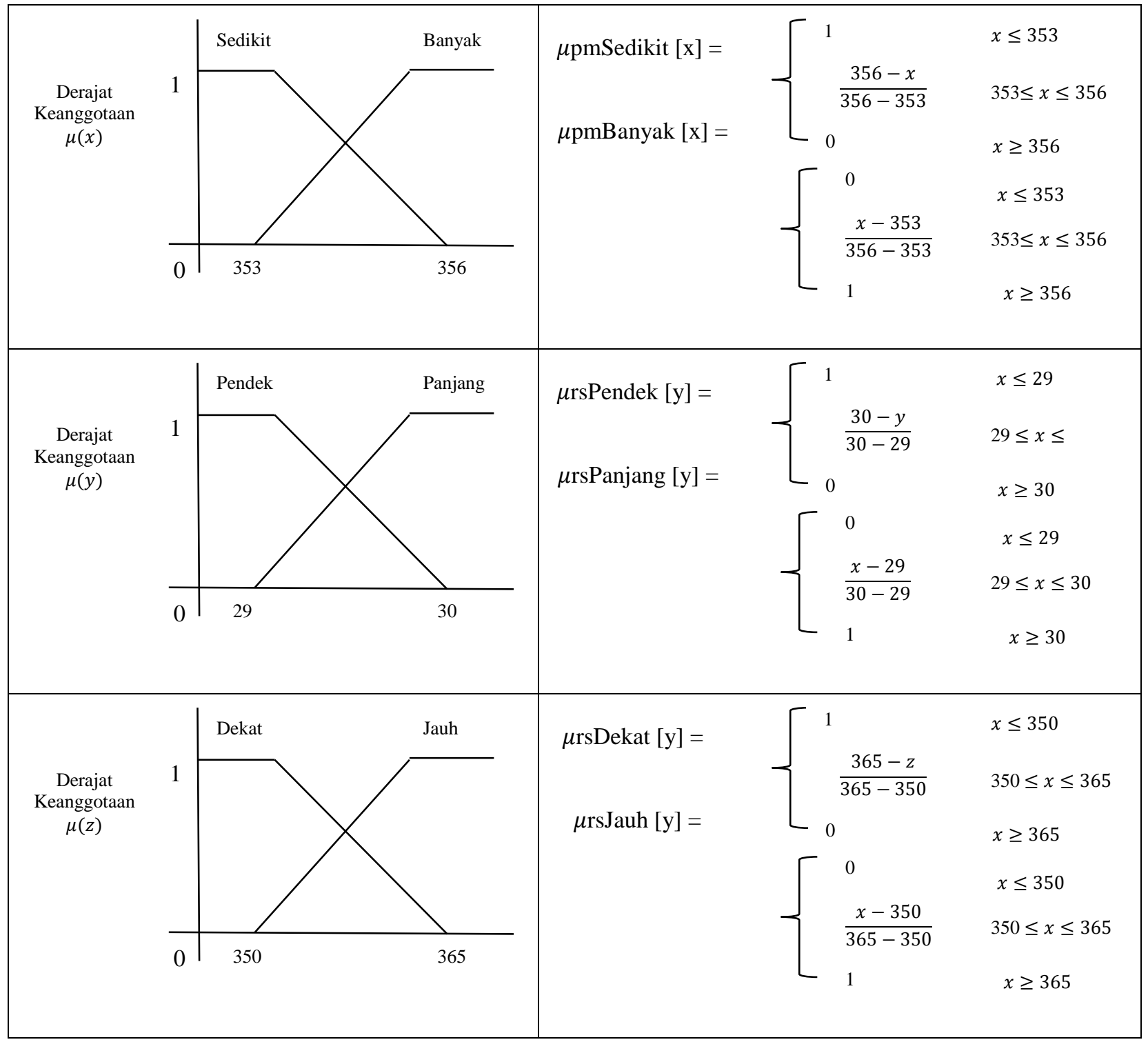

2. Fuzifikasi yaitu menentukan derajat keanggotaan variabel rasio awal Ramadhan satu ke awal Ramadhan berikutnya dan lama puasa Ramadhan pada setiap periode.

Data yang digunakan adalah data yang terdapat pada Tabel 1. Untuk memprediksi awal Ramadhan tahun 2020 maka data yang digunakan adalah data pada periode 2019-2020 dimana rasio awal Ramadhan tahun 2019 ke awal Ramadhan tahun $2020=$ 355 hari dan lama puasa Ramadhan pada periode 2019-2020 = 30 hari. Maka derajat keanggotaan rasio awal Ramadhan satu ke awal Ramadhan berikutnya pada himpunan banyak dan sedikit:

$$
\begin{aligned}
& \mu \operatorname{arSedikit~[355]}=\frac{356-355}{356-353}=0,33 \\
& \mu \operatorname{arBanyak~[355]}=\frac{355-353}{356-353}=0,67
\end{aligned}
$$


Derajat keanggotaan lama puasa Ramadhan pada himpunan Panjang dan Pendek:

$\mu$ prPendek [30] $=\frac{30-30}{30-29}=0$

$\mu$ prPanjang [30] $=\frac{30-29}{30-29}=1$

3. Pembentukan aturan dengan menggunakan logika IF THEN. Aturan yang digunakan pada penelitian ini terdiri dari empat aturan:

[R1] jika rasio awal Ramadhan satu ke awal Ramadhan berikutnya SEDIKIT dan lama puasa Ramadhannya PANJANG maka awal Ramadhan DEKAT dengan prediksi.

[R2] jika rasio awal Ramadhan satu ke awal Ramadhan berikutnya SEDIKIT dan lama puasa Ramadhannya PENDEK maka awal Ramadhan DEKAT dengan prediksi.

[R3] jika rasio awal Ramadhan satu ke awal Ramadhan berikutnya BANYAK dan lama puasa Ramadhannya PANJANG maka awal Ramadhan DEKAT dengan prediksi.

[R4] jika rasio awal Ramadhan satu ke awal Ramadhan berikutnya BANYAK dan lama puasa Ramadhannya PENDEK maka awal Ramadhan JAUH dengan prediksi.

4. Implikasi aturan dengan fungsi MIN dan menentukan nilai output masing-masing aturan.

$\alpha$-predikat 1 untuk [R1] dan nilai z1 yaitu:

$\alpha-$ predikat $1=\mu$ arSedikitn $\mu$ prPanjang $=\min (\mu \operatorname{arSedikit}[355], \mu$ prPanjang [30] $)$

$$
=\min (0,33 ; 1)=0,33
$$

Nilai z1 $=365-(0,33)(365-350)=360,05$

$\alpha$-predikat 2 untuk [R2] dan nilai z2 yaitu:

$\alpha-$ predikat $2=\mu$ arSedikitn $\mu$ prPendek $=\min (\mu \operatorname{arSedikit~[355],\mu prPendek~[30]~})$

$$
=\min (0,33 ; 0)=0
$$

Nilai z2 $=365-(0)(365-350)=365$

$\alpha$-predikat 3 untuk [R3] dan nilai z3 yaitu:

$\alpha-$ predikat $3=\mu$ arBanyak $\cap \mu$ prPanjang

$$
=\min (\mu \operatorname{arBanyak}[355], \mu \text { prPanjang [30] })
$$




$$
=\min (0,67 ; 1)=0,67
$$

Nilai z3 $=365-(0,67)(365-350)=354,95$

$\alpha$-predikat 4 untuk [R4] dan nilai z4 yaitu:

$\alpha-$ predikat $4=\mu$ arBanyakn $\mu$ prPendek

$$
=\min (\mu \operatorname{arBanyak}[355], \mu \operatorname{prPendek}[30])
$$

$$
=\min (0,67 ; 0)=0
$$

Nilai $\mathrm{z} 4=(365-350)(0)-350=-350$

5. Defuzzyfikasi menggunakan metode rata-rata

$$
\begin{aligned}
z & =\frac{\sum\left(a_{i} x z_{i}\right)}{\sum a_{i}} \\
& =\frac{(0,33)(360,05)+(0)(365)+(0,67)(354,95)+(0)(-350)}{0,33+0+0,67+0}=\frac{118,8165+0+237,8165+0}{1} \\
& =356,633
\end{aligned}
$$

Maka untuk memprediksi awal Ramadhan pada tahun 2020 menurut hasil metode Tsukamoto dapat menggunakan rasio $356,633 \approx 356$ hari dari awal Ramadhan tahun 2019.

\section{SIMPULAN DAN SARAN}

Berdasarkan pembahasan mengenai prediksi penentuan awal Ramadhan menggunakan metode Tsukamoto dengan dua variabel input berupa rasio awal Ramadhan satu dengan awal Ramadhan berikutnya dan lama puasa Ramadhan pada setiap periodenya dari tahun 20142020 serta variabel output berupa awal Ramadhan. Maka dapat disimpulkan bahwa tingkat prediksi menggunakan metode Tsukamoto sudah cukup baik diterapkan dalam penentuan awal Ramadhan. Hal ini terbukti dari hasil perbandingan perhitungan manual dengan perhitungan pada sistem metode tersebut yang memiliki selisih sangat kecil yakni pada perhitungan manual untuk menentukan awal Ramadahn 2020 diperoleh rasio 355 hari dari awal Ramadhan tahun 2019. Begitu juga dengan perhitungan dengan metode ini dalam menentukan awal Ramadhan 2020 diperoleh rasio 356 hari dari awal Ramadhan tahun 2019.

\section{DAFTAR PUSTAKA}

\section{Books:}

BJ Habibie. 1994. Rukyah dengan Teknologi Upaya Mencari Kesamaan Pandangan tentang Penentuan Awal Ramadhan dan Syawal. Jakarta: Gema Insani Press. 
Kusumadewi, S., dan Hartati, S. 2006. Neuro-Fuzzy Integrasi Sistem Fuzzy dan Jaringan Syaraf Tiruan. Yogyakarta: Graha Ilmu.

\section{Online journal:}

Asklany, S. A., Elhelow, K., Youssef, I. K., El-wahab, M. A. (2011). Rainfall Events Predictions Using Rule-Based Fuzzy Interference System. Journal of Atmospheric Research. Vol 101. Hal 228-236.

Dynes R. N., I Gusti N. R. U., \& Farida, A. W. 2012. Penerapan Fuzzy Inference System pada Penerapan Curah Hujan di Surabaya Utara. JURNAL SAINS DAN SENI ITS. $1(1): 25-27$.

Faisal, Y. Y. \& Faisal A. S. (2016). Metode Penentuan Awal Ramadhan Dan Hari Raya Menurut Ulama Dayah Aceh. 16(1): 9-13.

Ida, W. \& FadhliAlmu'iini, A. 2018. Pemodelan Fuzzy Inference System Tsukamoto Untuk Prediksi Curah Hujan Studi Kasus Kota Baru. Jurnal Ilmiah Teknologi Informasi Asia. 12(2): 116-117.

Jaenal Arifin. (2019). Dialektika Hubungan Ilmu Falak dan Penentuan Awal Ramadhan, Syawal, Dzulhijjah di Indonesia (Sinergi Antara Independensi Ilmuwan dan Otoritas Negara). 13(1): 44-51.

Mazenda, G., Soebroto, A. A., \& Dewi C. (2015). Implementasi Inference System (FIS) Metode Tsukamoto pada Sistem Pendukung Keputusan Penentuan Kualitas Air Sungai. DORO: Respository Jurnal Mahasiswa PTIIK Universitas Brawijaya, 1-11.

Restuputri, B. A., Mahmudy, W. F., \& Cholissodin, I. (2015). Optimasi Fungsi Keanggotaan Fuzzy Tsukamoto Dua Tahap Menggunakan Algoritma Genetika Pada Pemilihan Calon Penerima Beasiswa dan BBP-PPA (Studi Kasus : PTIIK Universiti Brawijaya Malang). Doro: Repository Jurnal Mahasiswa PTIIK Universitas Brawijaya, (15), 110.

Sri Widaningsih. 2017. Analisis Perbandingan Metode Fuzzy Tsukamoto, Mamdani, dan Sugeno dalam Pengambilang Keputusan Penentuan Jumlah Distribusi Raskin di Bulog Sub. Divisi Regional (Divre) Cianjur. Jurnal Informatika dan Manajemen STMIK. 11(1): 53. 